\title{
Inter and intra-guild interactions in egg parasitoid species of the soybean stink bug complex ${ }^{(1)}$
}

\author{
Edison Ryoiti Sujii( ${ }^{(2)}$, Maria Luiza Marcico Costa(3), Carmen Silvia Soares Pires ${ }^{(2)}$, Stefano Colazza(4) \\ and Miguel Borges ${ }^{(2)}$
}

\begin{abstract}
The objective of this research was to evaluate the parasitism behavior of Telenomus podisi Ashmead, Trissolcus basalis (Wollaston) e Trissolcus urichi Crawford (Hymenoptera: Scelionidae) on eggs of Nezara viridula L., Euschistus heros F., Piezodorus guildinii Westwood and Acrosternum aseadum Rolston (Heteroptera: Pentatomidae), in no choice and multiple choice experiments. For all parasitoid species, the results demonstrated the existence of a main host species that maximizes the reproductive success. The competitive interactions among the parasitoid species were investigated in experiments of sequential and simultaneous release of different combinations of parasitoid pairs on the hosts $N$. viridula, E. heros and A. aseadum. Exploitative competition was observed for egg batches at the genus level (Telenomus vs. Trissolcus) and interference competition at the species level (T. basalis vs. T. urichi). Trissolcus urichi was the most aggressive species, interfering with the parasitism of T. basalis. Generally, T. basalis showed an opportunistic behavior trying to parasitise eggs after T. urichi had abandoned the egg batch. The selection of parasitoid species for use in augmentative biological control programs should take into account the diversity of pentatomids present in soybean in addition to the interactions among the different species of parasitoids.
\end{abstract}

Index terms: parasitism, host-parasite relations, biological competition, pest control methods.

\section{Interações inter-guilda e intra-guilda entre espécies de parasitóides de ovos que atacam o complexo de percevejos da soja}

Resumo - O objetivo desta pesquisa foi avaliar o comportamento de parasitismo de Telenomus podisi Ashmead, Trissolcus basalis (Wollaston) e Trissolcus urichi Crawford (Hymenoptera: Scelionidae) em ovos de Nezara viridula L., Euschistus heros F., Piezodorus guildinii Westwood e Acrosternum aseadum Rolston (Heteroptera: Pentatomidae), em experimentos de múltipla escolha e sem escolha de hospedeiros. Todas as espécies de parasitóides testadas demonstraram possuir um hospedeiro que maximizou a sua capacidade reprodutiva. As interações competitivas entre espécies de parasitóides foram investigadas mediante experimentos de liberação seqüencial e simultânea de diferentes combinações de pares de espécies de parasitóides em $N$. viridula, E. heros e A. aseadum. Competição por exploração foi observada a nível de gênero (Telenomus vs. Trissolcus) e competição por interferência a nível de espécie (T. basalis vs. T. urichi). A espécie mais agressiva foi T. urichi, interferindo no parasitismo de T. basalis. Geralmente, T. basalis apresentou um comportamento oportunista tentando parasitar os ovos após T. urichi ter abandonado os lotes de ovos. A seleção de espécies de parasitóides para uso em programas de controle biológico aumentativo deve considerar a diversidade de pentatomídeos presentes na soja, além das interações entre as espécies de parasitóides que serão liberadas.

Termos para indexação: parasitismo, relação parasita-hospedeiro, competição biológica, métodos de combate às pragas.

\footnotetext{
${ }^{(1)}$ Accepted for publication on July 12, 2002. Supported by CNPq and Finep/Pronex.

(2) Embrapa-Centro Nacional de Pesquisa de Recursos Genéticos e Biotecnologia, Caixa Postal 02372, CEP 70849-970 Brasília, DF, Brazil. E-mail: sujii@cenargen.embrapa.br, cpires@cenargen.embrapa.br, mborges@cenargen.embrapa.br
}

\footnotetext{
(3) Instituto Brasileiro do Meio Ambiente, Av. L4, Ed. Sede do Ibama, CEP 70800-200 Brasília, DF, Brazil. E-mail: luiza@sede.ibama.gov.br

(4)Università degli Studi di Palermo, Istituto di Entomologia Agraria, Viale delle Scienze, 1390128 Palermo, Italy. E-mail: colazza@unipa.it
} 


\section{Introduction}

Stink bugs (Heteroptera: Pentatomidae) form a complex of species damaging soybean in Brazil. Species occurring in Brazilian soybean fields include Nezara viridula (L.), Euschistus heros (F.) and Piezodorus guildinii (Westwood). These species are considered the most important (Panizzi \& Slanski Junior, 1985; Panizzi \& Rossi, 1991) due to their abundance, wide geographic distribution and heavy damage on the crop. Other species, such as Edessa meditabunda F., Acrosternum aseadum (Rolston) and Thyanta perditor (F.) are relatively abundant, but produce less damage on the crop (Panizzi \& Slanski Junior, 1985). Among their natural enemies, several egg parasitoids (Hymenoptera: Scelionidae) have been documented and used as biological control agents worldwide (Corrêa-Ferreira \& Moscardi, 1996; Jones et al., 1996; Weber et al., 1996). The majority of these parasitoids are generalists, attacking eggs of various hosts (Esselbaugh, 1948; Sales, 1979; Buschman \& Whitcomb, 1980; Corrêa-Ferreira, 1991). This polyphagous behavior favors the use of these parasitoids as biocontrol agents, especially in cases when stink bug pest species occur simultaneously in soybean (Corrêa-Ferreira, 1993).

Telenomus spp. and Trissolcus spp. are solitary parasitoids that develop from egg to adult inside the host eggs. The life cycle of Trissolcus basalis (Wollaston) requires, on average, 17 hours for egg development, four days for larvae and six days for pupae (Corrêa-Ferreira, 1993). The female locates the host egg masses through random movements, and chemotaxy (Wilson, 1961; Sales, 1978; Vinson, 1984, 1985; Bin et al., 1993; Colazza et al., 1999). The initial contact with the egg mass is followed by the examination of eggs using the antennae. After the examination has been completed, the female either rejects the host or oviposits in it. After the deposition of the egg, the female marks the host by passing the ovipositor on the surface of the parasitized egg (Wilson, 1961; Collaza et al., 1996). This marking identifies eggs already parasitized and reduces superparasitism. Like T. basalis, Telenomus podisi Ashmead females are capable of ovipositing just after emergence, although the highest oviposition rate occurs on the second day after emergence for both. In general, these females deposit most of their eggs in their first week after emergence. A number of Scelionidae, including Trissolcus spp. and Telenomus spp., have been reported to be relatively long-lived (Orr, 1988).

Because the young of the egg parasitoids are limited into the resources on which they are deposited, the probability of survival and hence the reproductive success of the female parent depends critically on the host selection decision by the parent (Alphen \& Visser, 1990; Godfray, 1994; Vinson, 1998). On average, an unparasitized host will be a more valuable resource than a parasitized one. However, when hosts are in short supply relative to the parasitoid density, superparasitism may occur. It may occur as a result of exploitative competition, when each individual uses the resource and makes it unavailable for others, or through interference competition, where the individuals interacts aggressively with each other (Futuyma, 1992; Field, 1998). In competing solitary ectoparasitic wasp populations, both exploitative and interference competition have been observed (Wai \& Fujii, 1990). The possibility of competitive interactions among these scelionid species as well as their competitive ability could be applied to introduction strategies selecting parasitoid species based on pest species present in each site (Weber et al., 1996), particularly in augmentative biological control. Competitive ability may change the reproductive success of each parasitoid and the host mortality in a multiple species release strategy (Nechols et al., 1992; Follett et al., 2000).

The objective of this research was to evaluate the parasitism behavior of the scelionid egg parasitoids Telenomus podisi, Trissolcus basalis and Trissolcus urichi in different host species as Euschistus heros, Acrosternum aseadum, Nezara viridula and Piezodorus guildinii.

\section{Material and Methods}

\section{Insect rearing}

Adults of pentatomids, E. heros, A. aseadum, $N$. viridula and $P$. guildinii were collected in soybean fields and reared on sunflower seeds, soybeans, and green beans 
at $24 \pm 2^{\circ} \mathrm{C}, 70 \pm 10 \% \mathrm{RH}$ and 14 hours of photophase. Egg masses of each species were collected daily in order to maintain the parasitoid colonies and run the experiments. The eggs used in the experiments were selected by shape and color, excluding those flattened or transparent, to assure that egg mortality was predominantly caused by the parasitism (Borges et al., 1999).

The scelionids, T. podisi, T. basalis and T. urichi, were reared on egg masses of $E$. heros, in environmental chambers at $26.4 \pm 1^{\circ} \mathrm{C}, 60 \pm 10 \% \mathrm{RH}$ and 14 hours photophase. The adult parasitoids were fed with pure honey. After emergence, males and females were kept for 24 hours in glass tubes, $7.5 \times 1.3 \mathrm{~cm}$, containing pentatomid eggs to allow mating and parasitism. The mated females were then isolated in glass tubes for a 24 hours period in the absence of host eggs and fed with honey. When females completed 48 hours, they were used in the experiments as follow.

\section{No choice of host and reproductive success}

The reproductive success of parasitoid species was evaluated on each host in a series of no choice experiments. Female parasitoids were kept inside glass tubes $(7.5 \times 1.3 \mathrm{~cm})$ for six hours in the presence of a single stink bug egg mass 48-72 hours old glued to a cardboard. Each egg mass consisted of 30 or 45 eggs, depending on the daily oviposition capacity of parasitoid females. The eggs were then maintained in an environmental chamber at $26.4 \pm 1{ }^{\circ} \mathrm{C}, 60 \pm 10 \% \mathrm{RH}$ and 14 hours photophase until the emergence of parasitoids or eclosion of stink bug nymphs. Fifteen replicates of each host-parasitoid combination were performed.

\section{Multiple choice of host and reproductive success}

The reproductive success of parasitoid species was evaluated in experiments where the scelionids were kept in the presence of all host species in plastic Petri dishes (3.5 $\mathrm{cm}$ diameter) used as a multiple choice arena. Egg masses with ten eggs of each pentatomid were glued with honey on a paper card strip and arranged inside the arenas in a cross design equidistant from each other and from the center of the dish. A female parasitoid was released in the center of the arena and maintained inside it for six hours. Ten replicates were performed for each parasitoid species. After each trial, the batches were separated in glass tubes $(7.5 \times 1.3 \mathrm{~cm})$ and maintained in a controlled environmental chamber until the emergence of the parasitoids or eclosion of stink bug nymphs.

\section{Effect of the parasitoid interactions on performance of species}

\section{Sequential exploitation}

Response of female parasitoids to egg masses from the different pentatomid species previously parasitized or visited by a different species was evaluated. In each trial, one egg mass of the host was fixed in the center of the arena. One pair of female parasitoids combining the species T. podisi, T. basalis and T. urichi was tested in each trial. The first female parasitoid was released inside an arena and allowed to explore the resource for ten minutes, which included ovipositing or only visiting the egg mass. After this period, the first female was removed from the arena and the second female of the tested pair was released for ten minutes. The sequence of parasitoid species released inside the arena was subsequently reversed, allowing all species to be introduced onto the egg masses previously parasitized by other species. After the second parasitoid was removed, the egg masses were maintained in environmental chambers at $26.4 \pm 1{ }^{\circ} \mathrm{C}, 60 \pm 10 \% \mathrm{RH}$ and 14 hours photophase, until the emergence of the parasitoids or the eclosion of stink bug nymphs. The protocol described above was replicated at least 20 times with different individuals for each combination of parasitoid species.

\section{Simultaneous exploitation}

This experiment was also carried out in arenas following the same conditions as described in the previous study. However, female parasitoids from two different species were released simultaneously in the arena for ten minutes. Each combination of parasitoid species was tested at least ten times with different individuals. The behavior of aggression and intimidation displayed by one species or another was observed and recorded. The aggressive behavior occurred as one parasitoid approached one of the other species with very fast wing movements, back and forth, seeking to physically injure its competitor. The intimidation behavior was described as a surrounding movement combined with an antennal drumming and fast movement of the wings performed by the parasitoid, trying to guard the egg mass from its competitor. The stink bug egg masses were maintained in environmental chambers until the emergence of the parasitoids or the eclosion of stink bug nymphs.

\section{Data analysis}

The total egg mortality was calculated by considering all the eggs that failed to hatch, including infertile, 
unparasitized eggs, as well as those which were parasitized but failed to emerge (Borges et al., 1999). In all experiments, the average percentage of parasitized eggs, parasitoid emergence, and mortality of stink bug eggs were compared using ANOVA followed by the Student-Newman-Keuls test or the $t$ test for mean comparisons. When the data did not follow a normal distribution, the Kruskal-Wallis test, a non-parametric analysis of variance was used, followed by the Dunn's or Mann Whitney test for mean comparisons (Kuo et al., 1992; Sokal \& Rohlf, 1995).

\section{Results and Discussion}

\section{No choice of host and reproductive success}

All parasitoids species presented a general pattern with a more suitable host followed for a gradient of differentiated performance for the set of host species tested (Table 1). The reproductive success of $T$. podisi was significantly greater on eggs of $E$. heros and P. guildinii (ANOVA, $\mathrm{F}=35.03, \mathrm{DF}=58$, $\mathrm{P}<0.001$; Student-Newman-Keuls test, $\mathrm{P}<0.05$ ). Trissolcus urichi showed better reproductive success on $A$. aseadum followed by $E$. heros and $P$. guildinii (ANOVA, $\mathrm{F}=22.35, \mathrm{DF}=58, \mathrm{P}<0.01$ ). Adult emergence of $T$. podisi and T. urichi was not observed on eggs of $N$. viridula. Trissolcus basalis was the only species that completed the larval cycle in all four-host species. The highest emergence rate for T. basalis occurred on eggs of $N$. viridula and P. guildinii (ANOVA, $\mathrm{F}=4.4, \mathrm{DF}=58, \mathrm{P}<0.01$ ).

\section{Multiple choice of host and reproductive success}

The same relationship observed in the no choice experiment was found among parasitoid/host species when the scelionids were allowed to choose their host (Table 1). The highest emergence of T. podisi, T. basalis and T. urichi was observed on eggs of E. heros, N. viridula and A. aseadum, respectively. The emergence of T. podisi and T. basalis increased on preferred hosts when the females had the choice of hosts in which to oviposit. Trissolcus urichi exhibited similar patterns of parasitism on eggs of A. aseadum in both no choice and multiple choice situations.

\section{Host mortality}

The total percentage of embryo mortality, including attempted parasitism and natural infertility, was estimated for each parasitoid/host combination in the no choice and multiple choice experiments (Table 2). In general, for all parasitoid species, the mortalities observed for the preferential hosts were as high as those observed for the alternative hosts (i.e., T. podisi on E. heros, A. aseadum and P. guildinii; T. basalis on E. heros and N. viridula). Egg mortality increased due to parasitism attempt of T. basalis on E. heros, and T. urichi on N. viridula and $P$. guildinii (Tables 1 and 2). The percentage of

Table 1. Percentage of eggs (mean \pm standard error) from which adults of different species of egg parasitoids (Hymenoptera: Scelionidae) emerged when the females had no choice and when they had the multiple choice of host species (Heteroptera: Pentatomidae) for oviposition ${ }^{(1)}$.

\begin{tabular}{|c|c|c|c|c|}
\hline \multirow[t]{2}{*}{ Parasitoid species } & \multicolumn{4}{|c|}{ Host species } \\
\hline & E. heros & A. aseadum & N. viridula & P. guildinii \\
\hline & \multicolumn{4}{|c|}{ No choice of host species } \\
\hline Telenomus podisi & $41.3 \pm 3.7 \mathrm{a}$ & $4.4 \pm 3.1 \mathrm{c}$ & $0 \mathrm{c}$ & $31.1 \pm 4.8 \mathrm{~b}$ \\
\hline Trissolcus basalis & $22.8 \pm 3.1 b$ & $16.5 \pm 4.6 b$ & $44.2 \pm 6.6 \mathrm{a}$ & $36.4 \pm 8.5 \mathrm{ab}$ \\
\hline \multirow[t]{2}{*}{ Trissolcus urichi } & $28.7 \pm 3.7 \mathrm{~b}$ & $53.8 \pm 8.9 \mathrm{a}$ & $0 \mathrm{c}$ & $12.0 \pm 3.2 \mathrm{c}$ \\
\hline & \multicolumn{4}{|c|}{ Multiple choice of host species } \\
\hline Telenomus podisi & $69.0 \pm 9.9 \mathrm{a}$ & $0 \mathrm{~b}$ & $\mathrm{Ob}$ & $16.0 \pm 7.9 \mathrm{~b}$ \\
\hline Trissolcus basalis & $23.0 \pm 5.0 \mathrm{~b}$ & $1.0 \pm 1.0 \mathrm{c}$ & $86.0 \pm 4.0 \mathrm{a}$ & $0 \mathrm{c}$ \\
\hline Trissolcus urichi & $48.0 \pm 11.6 \mathrm{a}$ & $57.0 \pm 12.1 \mathrm{a}$ & $0 \mathrm{~b}$ & $26.0 \pm 12.3 \mathrm{ab}$ \\
\hline
\end{tabular}

${ }^{(1)}$ Means followed by the same letter in the row were not significantly different by Student-Newman-Keuls test $(\mathrm{P}<0.05)$; means of 15 and 10 observations in the no choice and multiple choice experiments respectively. 
emerged adults of $T$. basalis was low $(22.8 \pm 3.1 \%)$ on eggs of E. heros, however, $88.6 \pm 5.1 \%$ of the eggs did not develop into nymphs (Tables 1 and 2). The average of emerged adults of T. urichi on eggs of $N$. viridula and P. guildinii was $0 \%$ and $12.0 \pm 3.2 \%$, respectively (Table 1). However, $61.3 \pm 7.4 \%$ and $54.2 \pm 5.6 \%$ of $N$. viridula and P. guildinii eggs, respectively, did not develop into nymphs due to the parasitism (Table 2).

The absence of the offspring production does not indicate the absence of interaction in some parasitoid/host combinations. The parasitoids, in the absence of the preferred host and still keeping their reproductive capacity, invest part of their reproductive effort on non preferred hosts, running a risk. The results indicated that even having preferred hosts, the scelionid female attempted to parasite other species of pentatomids, although their offsprings do not develop on these species. These results are consistent with field surveys in the northern of Paraná State, Brazil, showing that, in general, the parasitoids attacked eggs of different species, but they occurred preferentially in a given host (Corrêa-Ferreira \& Moscardi, 1995).

\section{Effect of the parasitoid interactions on performance of species}

\section{Sequential exploitation}

The offspring production of parasitoids followed the performance pattern observed in the no-choice and multiple choice evaluations for all host species (Figure 1). In general, each parasitoid species produced the most progeny fitness when parasitizing its main host species. For example, T. basalis was the only parasitoid species that emerged from $N$. viridula. Release of T. basalis with any other parasitoid species and in any sequence did not change the emergence rate of T. basalis (ANOVA, $\mathrm{F}=0.33, \mathrm{DF}=0.33, \mathrm{P}=0.80)$. The emergence of $N$. viridula nymphs did not differ for any combination of parasitoids in sequential release (ANOVA, $\mathrm{F}=1.45, \mathrm{DF}=59, \mathrm{P}=0.22$ ). Although T. podisi and T. urichi were not able to produce offspring on $N$. viridula, these species produced the same rate of mortality observed on those trials with the presence of $T$. basalis.

All species of parasitoids emerged on E. heros eggs and their emergence rates did not differ significantly (Kruskal Wallis test; for T. basalis $\mathrm{H}=3.97, \mathrm{DF}=3, \mathrm{P}=0.27$, for $T$. podisi $\mathrm{H}=4.18$, $\mathrm{DF}=3, \mathrm{P}=0.24$ and for $T$. urichi $\mathrm{H}=5.98, \mathrm{DF}=3$, $\mathrm{P}=0.11)$ (Figure 1). The release of T. basalis followed by $T$. urichi caused the lowest emergence rates of E. heros nymphs, while combinations of parasitoids, which included T. podisi, did not differ significantly in the nymphal emergence (Kruskal Wallis ANOVA, $\mathrm{H}=18.84, \mathrm{DF}=5, \mathrm{P}=0.002$ ). The absence of $T$. urichi in the pair combinations resulted in higher survivorship and hatching of A. aseadum nymphs (see T. podisi/T. basalis $\mathrm{x}$ T. urichi/T. podisi, Kruskal Wallis ANOVA, $\mathrm{H}=12.33, \mathrm{DF}=5$, $\mathrm{P}=0.03$ ).

For all species combinations tested in the sequential trial, the release order of a given species of parasitoid did not affect the average rate of emerged parasitoids (Figure 1). In general, the tested

Table 2. Total mortality of eggs (mean \pm standard error) of different species of stink bugs (Heteroptera: Pentatomidae) as result of parasitism and natural mortality when the females (Hymenoptera: Scelionidae) had no choice and when they had the multiple choice of host species for oviposition ${ }^{(1)}$.

\begin{tabular}{lcccc}
\hline Parasitoid species & \multicolumn{4}{c}{ Host species } \\
\cline { 2 - 4 } & E. heros & A. aseadum & N. viridula & P. guildinii \\
\hline & & No choice of host species & $67.1 \pm 6.6 \mathrm{a}$ \\
Telenomus podisi & $66.7 \pm 4.6 \mathrm{a}$ & $43.6 \pm 6.3 \mathrm{~b}$ & $33.6 \pm 7.8 \mathrm{~b}$ & $68.1 \pm 6.7 \mathrm{~b}$ \\
Trissolcus basalis & $88.6 \pm 5.1 \mathrm{a}$ & $64.8 \pm 5.9 \mathrm{~b}$ & $75.0 \pm 4.6 \mathrm{ab}$ & $54.2 \pm 5.6 \mathrm{~b}$ \\
Trissolcus urichi & $65.0 \pm 4.9 \mathrm{~b}$ & $88.4 \pm 5.1 \mathrm{a}$ & $61.3 \pm 7.4 \mathrm{~b}$ & $51.0 \pm 10.3 \mathrm{~b}$ \\
\hline & & Multiple choice of host species & $15.0 \pm 5.4 \mathrm{~b}$ \\
Telenomus podisi & $90.0 \pm 8.9 \mathrm{a}$ & $63.0 \pm 13.4 \mathrm{ab}$ & $41.0 \pm 9.0 \mathrm{~b}$ & $65.0 \pm 12.5 \mathrm{a}$ \\
Trissolcus basalis & $78.0 \pm 13.1 \mathrm{a}$ & $18.0 \pm 4.9 \mathrm{a}$ & $93.0 \pm 26.0 \mathrm{~b}$ & $63.0 \pm 1.0 \mathrm{a}$ \\
Trissolcus urichi & $74.0 \pm 8.5 \mathrm{a}$ & $85.0 \pm 6.9 \mathrm{a}$ & 6
\end{tabular}

${ }^{(1)}$ Means followed by the same letter in the row were not significantly different by Student-Newman-Keuls test $(\mathrm{P}<0.05)$; means of 15 and 10 observations in the no choice and multiple choice experiments respectively. 
parasitoid species did not avoid eggs marked by the first released species. At least, they attempted to probe the eggs and, in many cases, they parasitized and marked them again. This interspecific superparasitism deceased a large number of eggs and could explain differences in the mortality rates of eggs and emergence of parasitoids in relation to the same parameters observed in the multiple and no-choice trials.

\section{Simultaneous exploitation}

Eggs of $N$. viridula exposed simultaneously to pairs of parasitoid species produced only offspring of T. basalis (Figure 2). There was an increase in the number of the produced offspring of T. basalis when it was exposed to $N$. viridula eggs simultaneously with $T$. podisi $(\mathrm{t}$ test, $\mathrm{t}=2.21$, $\mathrm{DF}=18, \mathrm{P}=0.04) . T$. podisi and T. urichi were not able to produce offspring on $N$. viridula. Although emergence rates from $N$. viridula eggs observed in the three tested parasitoid combinations were not statistically different, a lower survivorship on the stink bug eggs was observed when $T$. basalis was present $(\mathrm{ANOVAF}=1.05, \mathrm{DF}=29, \mathrm{P}=0.37$ ).

In the presence of the host $E$. heros, there was no difference in the number of offspring produced by T. urichi and T. podisi in any of the tested parasitoid combinations (Mann Whitney test; $\mathrm{T}=67.5, \mathrm{P}=0.7$ for $T$. urichi, and $\mathrm{T}=100.0, \mathrm{P}=0.43$ for $T$. podisi) (Figure 2). However, considering the total number of emerged parasitoids in the different treatments, the highest emergence rate was observed when T. urichi and T. podisi were released simultaneously. The survivorship of E. heros embryo was reduced significantly by the presence of $T$. podisi (see the combinations of T. urichi - T. podisi and T. basalis - T. podisi, Kruskal Wallis, $\mathrm{H}=8.06, \mathrm{DF}=2$, $\mathrm{P}=0.018$ ). When $A$. aseadum was used as host, the adult emergence rates of parasitoids were very low or even null for all the tested combinations of parasitoid species. There was not significant difference on the mortality rates of A. aseadum in any of the tested parasitoid combinations (ANOVA $\mathrm{F}=2.7, \mathrm{DF}=24, \mathrm{P}=0.09$ ).

The interaction between the parasitoid species was observed on these experiments and both
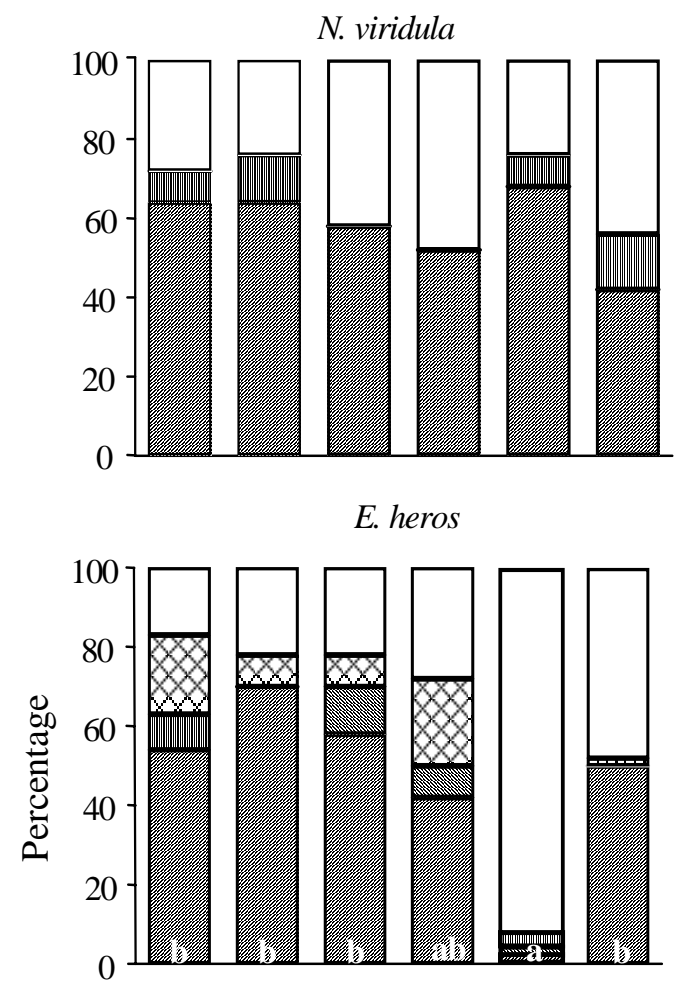

A. aseadum

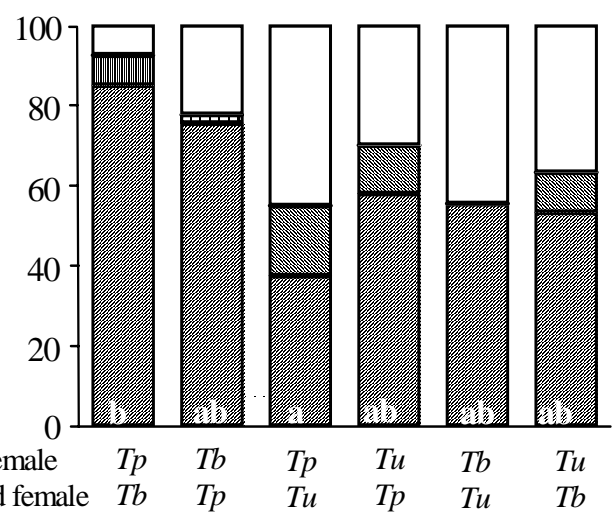

$\begin{array}{lllllll}\text { First female } & T p & T b & T p & T u & T b & T u \\ \text { Second female } & T b & T p & T u & T p & T u & T b\end{array}$

Figure 1. Emergence of parasitoids, eclosion of stink bug nymphs ( $\square$ ) and egg mortality $(\square)$ due to parasitism attempt observed on the sequential liberation of different combinations of scelionid species. Tp: Telenomus podisi (囚), Tb: Trissolcus basalis ( $\square)$, Tu: Trissolcus urichi $(\square)$. For Euschistus heros and Acrosternum aseadum data, different letters on black portion of columns indicate significant difference (Kruskal Wallis ANOVA; $\mathrm{H}=18.84, \mathrm{DF}=5, \mathrm{P}=0.002$ for $E$. heros and $\mathrm{H}=12.33$, $\mathrm{DF}=5, \mathrm{P}=0.03$ for $A$. aseadum . 
aggressive and intimidation behaviors were recorded. None of the parasitoid species respected the marked eggs left by their competitors. Trissolcus urichi demonstrated the aggressive behavior more frequently in the presence of $T$. basalis. The aggressive behavior of $T$. urichi increased in relation to the host preference level of $T$. basalis. When the host was $N$. viridula, the proportion of aggressive behavior was 0.8 . For $E$. heros, a secondary host for T. basalis, the observed proportion was 0.4 , and for A. aseadum, an occasional host, the proportion was 0.2 . Additionally, T. urichi demonstrated the behavior of guarding against intruders even when it was not in the presence of its main host species. In simultaneous patch visit situations, the best decision of when to leave the patch depended on the actions of the competitors. Alphen \& Visser (1990) showed that a parasitoid leaving a patch where competitors were still searching could lose offspring, because it left the parasitized hosts vulnerable to be attacked by competitors. Sometimes, a way to counteract that potential loss was to stay longer and to superparasitize. Due to the time spent defending the patches by fighting intruders, parasitism rates were reduced, causing loss to the offspring production.

Trissolcus basalis seemed to be the most opportunistic species. Generally, it waited until the competitors had left the egg masses before approaching and parasitizing them. The most frequent behavior observed in T. podisi was the intimidation approach, where it tried to guard the egg masses from the others, especially $T$. basalis. Also, it was noticed that for $T$. podisi the aggression and intimidation behaviors occurred mostly when it was tested on a preferred host. On the other hand, for T. urichi, these two approaches were observed independently of the host species whenever T. basalis was elected to be its competitor.

The studied interactions among the tested parasitoid demonstrated an exploitative competition at the genus level (Telenomus $\mathrm{x}$ Trissolcus) and an interference competition at the species level (T. basalis $\mathrm{x} T$. urichi). In the experiment of sequential release, the females tried to parasitize most of the available resources. Although the response was typically avoidance, some females laid eggs in hosts

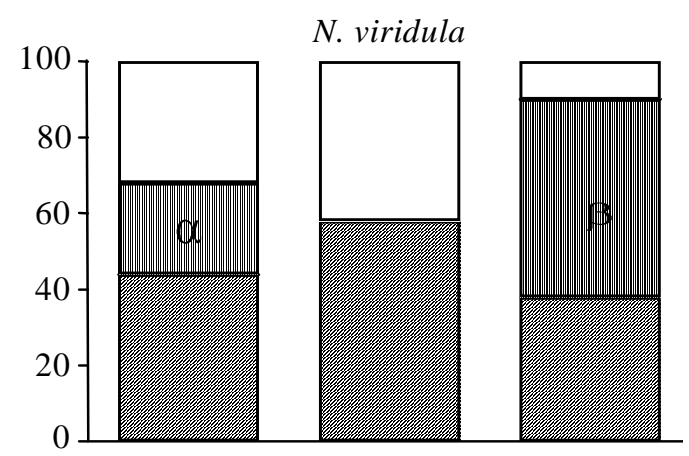

E. heros

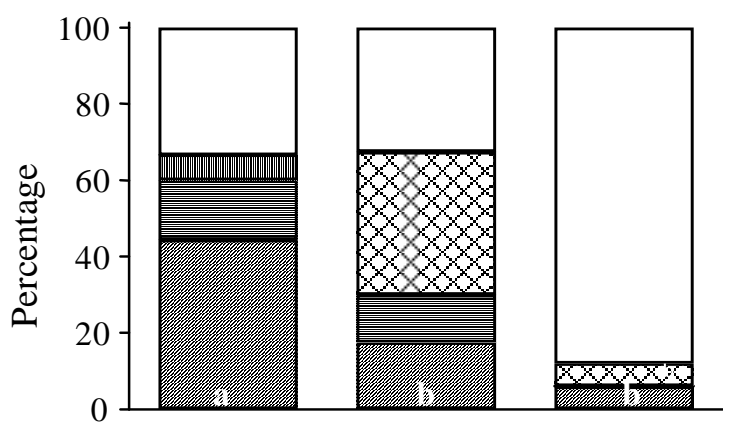

A. aseadum

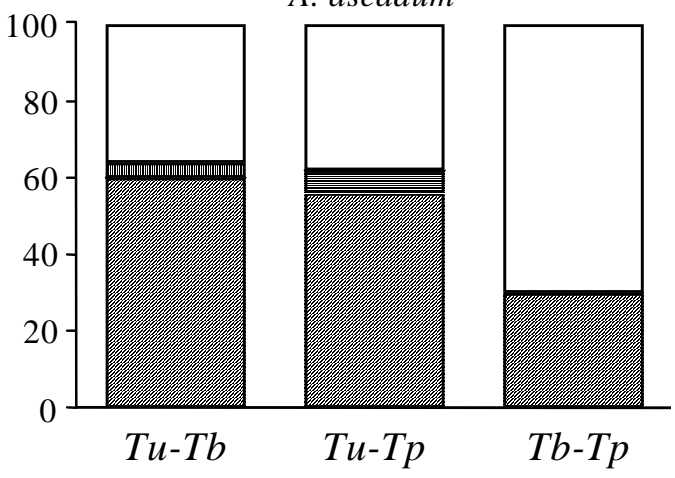

Figure 2. Emergence of parasitoids, eclosion of stink bug nymphs (四) and egg mortality $(\square)$ due to parasitism attempt observed on the simultaneous liberation of different combinations of scelionid species. Tp: Telenomus podisi (囚), Tb: Trissolcus basalis ( $\square)$, Tu: Trissolcus urichi $(\exists)$. For Nezara viridula different symbols on stripped portion of columns indicate significant difference ( $t$ test, $\mathrm{t}=2.21, \mathrm{DF}=18, \mathrm{P}=0.04)$ and same letters on black portion of columns indicate no significant difference (ANOVA, $\mathrm{F}=1.05, \mathrm{DF}=29, \mathrm{P}=0.37$ ). For Euschistus heros different letters on black portion of columns indicate significant difference (Kruskal Wallis test, $\mathrm{H}=8.06, \mathrm{DF}=2$, $\mathrm{P}=0.018$ ). 
already parasitized and marked by other females. Even when superparasitism occurred, only one individual emerged as a consequence of elimination of the competitors at the first larval stage. For T. basalis, the competition for the same mass of eggs by various females blocked the ability of the parasitoid to discriminate and avoid the oviposition in eggs already parasitized (Corrêa-Ferreira, 1993; Colazza et al., 1996). The superparasitism, in this species, seems to be occasional and very low in field conditions. However, in laboratory conditions, this behavior can be frequently observed under oviposition pressure (Corrêa-Ferreira, 1993; Field, 1998).

The selection of parasitoid species for use in biological control programs should take into account the diversity of pentatomids present in the soybean area and the interactions among the different species of parasitoids. In this way, regions where $N$. viridula and $P$. guildinii are the most abundant species, the inoculative releases of T. basalis would succeed. Otherwise, in areas where $E$. heros is the predominant species, T. podisi should be the species chosen for biological programs. Additionally, regions with equal ratios in stink bug abundance would likely be successfully controlled using a mixture of $T$. basalis and $T$. podisi. These assumptions are based on the fact that each parasitoid has a preferential host, although they would lay their eggs in whichever host is available. Furthermore, the parasitism behavior of T. basalis and T. podisi maximizes the use of resources, hence avoiding interference competition between the females of both species. This favors the maintenance of both species in the environment resulting in increased populations.

\section{Conclusions}

1. The use of egg parasitoids as biocontrol agents against soybean stink bugs should be based on the stink bug species diversity present in each area.

2. Mass release of multiple species of egg parasitoids should prevent the use of species belonging to same genera in order to maximize competitive exploitation for preys and avoid interference competition that reduces parasitism rates.
3. Mass release of parasitoids against their alternative host may control the local populations, but the efficiency could be variable and the parasitoid population will not establish due to the low rates of offspring emergence in the absence of the main host species.

\section{Acknowledgements}

To João Almeida, Marcelo Scarpati, Hélio Santos, Diva Tiburcio and Cláudia Brod for helping with field collecting and laboratory rearing the insects used in this study; to Ms. Carolyn Smith for reviewing the paper.

\section{References}

ALPHEN, J. J. M. van; VISSER, M. E. Superparasitism as an adaptative strategy for insect parasitoids. Annual Review of Entomology, Palo Alto, v. 35, p. 59-74, 1990.

BIN, F.; VINSON, S. B.; STRAND, M. R.; COLAZZA, S.; JONES JUNIOR, W. A. Source of an egg kairomone for Trissolcus basais, a parasitoid of Nezara viridula. Physiological Entomology, Oxford, v. 18, p. 7-15, 1993.

BORGES, M.; COSTA, M. L. M.; SUJII, E. R.; CAVALCANTI, M. G.; REDIGOLO, G. F.; RESCK, I. F.; VILELA, E. F. Semichemical and physical stimuli involved in host location and acceptance by Telenomus podisi (Hymenoptera: Scelionidae) towards Euschistus heros (Heteroptera: Pentatomidae). Physiological Entomology, Oxford, v. 24, p. 227-233, 1999.

BUSCHMAN, L. L.; WHITCOMB, W. H. Parasites of Nezara viridula (Hemiptera: Pentatomidae) and other hemiptera in Florida. Florida Entomologist, Homestead, v. 63 , p. 154-162, 1980.

COLAZZA, S.; ROSI, M. C.; SEBASTIÁN, P.; URSINI, M. Host acceptance behavior in the egg parasitoid Trissolcus basalis (Hymenoptera: Scelionidae). Acta Oecologica, Paris, v. 17, p. 109-125, 1996.

COLAZZA, S.; SALERNO, G.; WAJNBERG, E. Volatile and contact chemicals released by Nezara viridula (Hemiptera: Pentatomidae) have a kairomonal effect on the egg parasitoid Trissolcus basalis (Hymenoptera: Scelionidae). Biological Control, San Diego, v. 16, p. 310317, 1999.

CORRÊA-FERREIRA, B. S. Parasitóides de ovos de percevejos: incidência natural, biologia e efeito sobre a 
população de percevejos da soja. 1991. 229 f. Tese (Doutorado em Entomologia) - Universidade Federal do Paraná, Curitiba, 1991.

CORREAA-FERREIRA, B. S. Utilização do parasitóide de ovos Trissolcus basalis (Wollaston) no controle de percevejos da soja. Londrina: Embrapa-CNPSo, 1993. 40 p. (Circular Técnica, 11).

CORRÊA-FERREIRA, B. S.; MOSCARDI, F. Biological control of soybean stink bugs by inoculative releases of Trissolcus basalis. Entomologia Experimentalis et Applicata, Dordrecht, v. 79, p. 1-7, 1996.

CORRÊA-FERREIRA, B. S.; MOSCARDI, F. Seasonal occurrence and host spectrum of egg parasitoids associated with soybean stink bugs. Biological Control, San Diego, v. 5, p. 196-202, 1995.

ESSELBAUGH, C. O. Notes on the bionomics of some Midwestern Pentatomidae. Entomologica Americana, New York, v. 28, p. 1-73, 1948.

FIELD, S. A. Patch exploitation, patch-leaving and preemptive patch defense in the parasitoid wasp Trissolcus basalis (Insecta: Scelionidae). Ethology, Berlin, v. 104, p. 323-338, 1998.

FOLLETT, P. A.; DUAN, J.; MESSING, R. H.; JONES, V. P. Parasitoid drift after biological control introduction: re-examining Pandora's box. American Entomologist, Lanham, v. 46, p. 82-94, 2000.

FUTUYMA, D. J. Biologia evolutiva. 2. ed. Ribeirão Preto: Sociedade Brasileira de Genética/CNPq, 1992. $646 \mathrm{p}$.

GODFRAY, H. C. J. Parasitoids: behavioral and evolutionary ecology. Princeton: Princeton University Press, 1994. 473 p.

JONES, W. A.; SHEPARD, B. M.; SULLIVAN, M. J. Incidence of parasitism of pentatomid (Heteroptera) pests of soybean in South Carolina with a review of studies in other States. Journal of Agricultural Entomology, Clemson, v. 13, p. 243-262, 1996.

KUO, J.; FOX, E.; MacDONALD, S. Sigmastat: statistical software for working scientists. San Francisco: Jandel Scientific, 1992. 660 p.

NECHOLS, J. R.; KAUFFMAN, C. R.; SCHAEFER, P. W. Significance of host specificity in classical biological control. In: NECHOLS, J. R.; KAUFFMAN, C. R. (Ed.). Selection criteria and ecological consequences of importing natural enemies. Lanham: Entomological
Society of America, 1992. p. 41-52. (Proceedings Thomas Say Publications in Entomology).

ORR, D. B. Scelionid wasps (Wollaston) as biological control agents: a review. Florida Entomologist, Homestead, v. 71, p. 506-528, 1988.

PANIZZI, A. R.; ROSSI, C. E. The role of Acanthospernum hispidum in the phenology of Euschistus heros and Nezara viridula. Entomologia Experimentalis et Applicata, Dordrecht, v. 59, p. 67-74, 1991.

PANIZZI, A. R.; SLANSKI JUNIOR, F. Review of phytophagous pentatomids (Hemiptera: Pentatomidae) associated with soybeans in Americas. Florida Entomologist, Homestead, v. 68, p. 184-214, 1985.

SALES, F. M. Responsiveness and threshold for host seeking stimulation of the female Trissolcus basalis (Wollaston) by the eggs of the host Nezara viridula (L.). Fitossanidade, Fortaleza, v. 3, p. 36-39, 1979.

SALES, F. M. Temporal analysis of the ovipositional behavior of the female egg parasitoid, Trissolcus basalis (Wollaston). Fitossanidade, Fortaleza, v. 2, p. 80-83, 1978.

SOKAL, R. R.; ROHLF, F. J. Biometry: the principles and practice of statistics in biological research. 3. ed. New York: W. H. Freeman, 1995. 887 p.

VINSON, S. B. Parasitoid-host relationship. In: BELL, W. J.; CARDE, R. T. (Ed.). Chemical ecology of insects. New York: Chapman and Hall, 1984. p. 205-233.

VINSON, S. B. The behavior of parasitoids. In: KERDUT, G. A.; GILBERT, L. I. (Ed.). Comprehensive insect physiology biochemistry and pharmacology. New York: Pergamon, 1985. v. 9, p. 417-469.

VINSON, S. B. The general host selection behavior of parasitoid Hymenoptera and a comparison of initial strategies utilized by larvaphagous and oophagous species. Biological Control, San Diego, v. 11, p. 79-96, 1998.

WAI, K. M.; FUJII, K. Intraspecific competition among wasps parasite of bean weevil larvae. Researches on Population Ecology, Kyoto, v. 32, p. 85-98, 1990.

WEBER, C. A.; JANET, M. S.; EHLERAND, L. E.; ZALOM, F. G. Ovipositional behavior and host discrimination in three scelionid egg parasitoids of stink bugs. Biological Control, San Diego, v. 6, p. 245-252, 1996.

WILSON, F. Adult reproductive behavior in Assolcus basalis (Hymenoptera: Scelionidae). Australian Journal of Zoology, Collingwood, v. 9, p. 739-751, 1961. 